\title{
Metode Pemetaan Pikiran Dalam Pembelajaran Sejarah Jepang: Studi Kasus Mahasiswa Bahasa Dan Kebudayaan Jepang
}

\author{
Dewi Saraswati Sakariah \\ Universitas Diponegoro, Semarang, Indonesia \\ +6285255892281 \\ sarasdewiq@gmail.com
}

\begin{abstract}
Abstrak
Penelitian ini bertujuan untuk meningkatkan pemahaman mahasiswa selama pembelajaran mata kuliah Sejarah Jepang dengan menggunakan metode belajar pemetaaan pikiran (mind mapping) milik Tony Buzan. Penelitian ini merupakan jenis penelitian tindakan kelas yang subjeknya dari adalah mahasiswa Bahasa dan Kebudayaan Jepang semester 3 (kelas A dan B) dengan objek penelitian adalah kemampuan memahami mahasiswa terhadap materi Sejarah Jepang era primitif (Jomon-Yayoi-Kofun) dan era kerajaan akhir (Heian) yang menggunakan beberapa rujukan buku dengan metode pengujian dari hasil penerapan pemetaan pikiran. Hasil dari penelitian ini menunjukkan bahwa penerapan metode pembelajaran pemetaan pikiran/Mind Mapping dapat membuat mahasiswa lebih bersemangat dalam proses belajar dan memberikan hasil yang optimal dalam nilai akademisnya.
\end{abstract}

Kata Kunci: Sejarah; Mind Mapping; Tony Buzan

\section{Pendahuluan}

Pengajar tentunya memiliki target capaian pembelajaran dengan harapan bahwa peserta didiknya mampu untuk mencapai target tersebut di akhir pembelajaran. Dalam hal ini, substansi yang paling utama adalah pemahaman mahasiswa itu sendiri terhadap materi pembelajaran yang telah disampaikan.

Mata kuliah Sejarah Jepang merupakan salah satu mata kuliah yang diberikan oleh program studi Bahasa dan Kebudayaan Jepang, Fakultas Ilmu Budaya, Universitas Diponegoro kepada mahasiswa di setiap tahun ajaran ganjil. Mata kuliah ini terdiri dari 2 SKS yang telah dirancang memiliki target-target tertentu yang perlu dicapai oleh setiap mahasiswa pada setiap tatap mukanya. Dalam deskripsinya, mata kuliah ini secara umum fokus pada pengenalan periodisasi zaman perkembangan masyarakat Jepang sejak zaman pra sejarah hingga era modern (Zaman Meiji, 18681912). Oleh karena itu membutuhkan kemampuan dalam mengingat dan memahami fakta dan peristiwa yang ada pada materi-materi yang diajarkan.

Setelah beberapa kali mengampu mata kuliah ini, pengajar merasakan bahwa pengajaran materi sejarah menemui beberapa kendala dalam prosesnya, seperti; 1) Pembelajaran sifatnya masih informatif. 2) Hanya terpusat pada pengajar. 3) Mahasiswa cenderung pasif pada sesi tanya-jawab dan 4) Mahasiswa masih menghapal tanpa dapat memahami lebih dalam

Ditambah lagi dengan materi yang cukup banyak dan membutuhkan ingatan yang kuat, sehingga mahasiswa cenderung menghafalkan materi ketimbang memahami terutama saat ujian akan dilakukan. Sebagaimana umum diketahui bahwa pemahaman akan lebih baik daripada menghafal, dan dengan memahami maka ilmu yang telah diperoleh dapat melekat di pikiran kita hingga tidak mudah dilupakan, maka pengajar berusaha 
mencari metode pengajaran lain yang berbeda guna meningkatkan pemahaman mahasiswa terhadap materi sejarah yang diberikan. Hal ini sesuai dengan substansi dari proses pembelajaran itu sendiri yakni pembelajaran merupakan bantuan yang diberikan pendidik agar dapat terjadi proses pemerolehan ilmu dan pengetahuan, penguasaan, kemahiran dan tabiat, serta pembentukan sikap dan kepercayaan pada peserta didik.(Nurhasanah et al., 2019)

Ini juga merupakan tanggung jawab sebagaimana yang tertuang dalam UU mengenai Guru dan Dosen bahwa dosen adalah pendidik profesional dan ilmuwan dengan tugas utama mentransformasikan, mengembangkan, dan menyebarluaskan ilmu pengetahuan, teknologi, dan seni melalui pendidikan, penelitian dan pengabdian kepada masyarakat (JDIH, 2005). Sikap profesionalisme yang dituntut ke setiap pengajar mengharuskan pengajar perlu meningkatkan mutu dan kualitas produk pengajarannya. Oleh karena itu, sebagai salah satu bentuk inovasi yang dilakukan adalah dengan membuat variasi dalam mengajar agar mahasiswa tidak bosan. Sebagaimana yang dikatakan oleh Saiman dalam penelitiannya bahwa pembelajaran apapun yang dilakukan jika monoton pasti membuat siswa jenuh, bosan, dan akhirnya kurang berminat. Dan ini memang terjadi dalam pembelajaran sejarah, karena terkonsentrasi pada penerapan metode ceramah (Saiman, 2011). Selain itu, dalam proses belajar mengajar juga diperlukan sifat terbuka dan dialogis dimana mengharuskan guru sejarah untuk tidak menganggap dirinya sebagai satusatunya sumber kebenaran di kelas, jadi fokusnya bukan berpusat pada guru lagi tapi idelanya ke mahasiswa sebagai peserta didik dan yang paling menerima manfaat dari proses ini.
Adapun metode pembelajaran yang digunakan adalah metode belajar memetakan pikiran atau disebut mind map dimana metode ini digunakan untuk membantu seseorang dalam memproses informasi, memunculkan ide-ide baru, memperkuat ingatan, mengoptimalkan waktu sebaik-baiknya dan meningkatkan cara bekerja (dalam hal ini memahami informasi dalam belajar). (Buzan, 2018). Dalam penelitiannya, Nikhilkumar D. Parikh menerangkan bahwa metode ini efektif digunakan dalam meningkatkan nilai akademik dan lebih efektif dibanding menggunakan cara tradisional dalam meningkatkan pemahaman dalam mata pelajaran ilmu sosial(Nikhilkumar D. Parikh, 2016). Penerapan metode pemetaan pikiran juga disarankan oleh Astawa dalam proses belajar mengajar mata pelajaran sosial dikarenakan dapat meningkatkan minat pembelajarnya dan terbukti meningkatkan prestasi pembelajarnya disbanding mereka yang tidak belajar dengan menggunakan metode mind mapping ini. (Astawa, 2019). Dengan begitu, di sini peneliti ingin melihat sejauh mana metode pemetaan pikiran dapat meningkatkan pemahaman mahasiswa terhadap materi di kelas sejarah.

\section{Metode Penelitian}

Penelitian tindakan kelas merupakan penelitian terapan, di mana hasilnya digunakan untuk diterapkan sebagai pengalaman praktis. (Sudiarditha, 2011) Ada yang menyebutkan bahwa penelitian ini memiliki ciri seperti penelitian kualitatif (karena datanya tidak memerlukan perhitungan secara statisitik) dan eksperimen (karena diawali dengan perencanaan, perlakuan terhadap subjek penelitian dan adanya evaluasi hasil yang dicapai setelah perlakuan). (Arikunto et al., 
2015) Jenis penelitian tindakan kelas (PTK) adalah penelitian yang memaparkan terjadinya sebab-akibat dari perlakuan, sekaligus memaparkan apa saja yang terjadi ketika perlakuan diberikan, dan memaparkan seluruh proses sejak awal pemberian perlakuan sampai dengan dampak dari perlakuan tersebut.

Dalam penelitian tindakan kelas ini, kegiatan pengajar dari perencanaan, pelaksanaan, dan hasil yang diperoleh secara rinci dan lengkap wajib dilaporkan. Pelaku tindakan adalah pengajar dengan mahasiswa yang berstatus sebagai subjek tindakan melakukan kegiatan yang diperintahkan oleh pengajar(Arikunto et al., 2015). Adapun prinsip yang dijaga oleh peneliti selama melakukan penelitian ini adalah melakukan penelitian dalam kelas yang terjadwal seperti biasa dalam bentuk tugas individu dan bertujuan untuk perbaikan mutu pembelajaran pada mata kuliah Sejarah Jepang, sehingga dilakukan dengan sukarela tanpa paksaan.

Metode pembelajaran yang digunakan adalah metode pemetaan pikiran yang digagas oleh Tony Buzan. Dalam bukunya bahwa metode ini adalah sebuah cara yang kreatif dan efektif dalam memetakan pikiran-pikiran kita dengan sederhana serta merupakan rute yang hebat dalam ingatan yang memungkinkan kita menyusun fakta sedemikian rupa. (Buzan, 2008). Dengan begitu akan memudahkan pembuatnya dalam mengingat informasi daripada menggunakan teknik catat yang tradisional. Dengan menggunakan teknik ini pula, daftar ingormasi yang panjang bisa disederhanakan dengan cara yang kreatif. (Buzan, 2004)

Adapun sasaran tindakan kelas adalah mahasiswa pada mata kuliah Sejarah Jepang yang terbagi menjadi 2 kelas, yakni kelas A dan kelas B dengan materi yang diujikan adalah materi pada pertemuan tatap muka ke-2 dan ke-5, yakni kehidupan pra sejarah dan periode akhir istana. Tindakan kelas dilakukan dengan mengawali ceramah mengenai materi tersebut secara garis besar yang didampingi dengan buku referensi. Mahasiswa kemudian menerima instruksi membuat pemetaan pikiran terkait materi dengan panduan yang telah disederhanakan dari buku penulisnya, yakni Tony Buzan. Karya mahasiswa dikumpulkan pada folder kelas pada aplikasi Microsoft Teams (Akoojee and Nkomo, 2007). Pengujian sejauh mana pemahaman mereka tidak diujikan saat itu juga, namun pada pertemuan berikutnya.

Untuk mengetahui sejauh mana pemahaman para subjek penelitian, maka pengujian dibagi menjadi dua siklus dengan metode pilihan ganda dan essay kemudian membandingkan hasil dari kedua kelas tersebut.

Sumber utama dalam penelitia ini adalah karya mind mapping mahasiswa dan hasil ujian singkat. Adapun sumber penunjang yakni beberapa referensi yang diberikan:

- A History of Japan from Stone Age to Superpower (Henshall, 1999)

- Virtual Library (Google, n.d.)

- Buku Pintar Mind Map (Terjemahan)(Buzan, 2005)

- Bahan presentasi ( Sakariah, 2021)

\section{Hasil dan Pembahasan}

Hasil penelitian menunjukkan bahwa penerapan metode pembelajaran mind mapping pada mata kuliah Sejarah Jepang pada kelas A dan B memberikan dampak pemahaman yang besar bagi mahasiswa. Dengan menggunakan metode ini dengan tepat, maka memberikan hasil yang memuaskan bagi nilai akademis mahasiswa. 
Sebagaimana melihat tujuan awal dari metode pemetaan pikiran yang dirumuskan oleh Tony Buzan, maka untuk mencapai hasil maksimal dalam meningkatkan pemahaman, maka terdapat kaidah atau aturan tertentu yang perlu ditaati oleh mahasiswa, yakni pembuatan mind map itu sendiri, seperti; melibatkan 3 lebih warna, foto, simbol, dan bentuk sebagai pemicu daya ingat pembuatnya.

Pelaksanaan penelitian terdiri dari tahap persiapan, pelaksanaan, dan pengujian. Tahap persiapan dimulai dari menentukan sampel atau subjek penelitian yakni mahasiswa kelas A dan B jenjan tahun kedua di mata kuliah Sejarah Jepang, menyediakan beberapa referensi dalam pengerjaan mind mapping, mendesain waktu bergantian pemberian tindakan pada kedua kelas tersebut pada silabus yang telah dibuat.

Tahap pelaksanaan dilakukan di waktu berbeda pada kedua kelas. Dimulai dengan kelas B di minggu ke-2 dan kelas A di minggu ke-4 perkuliahan. Mahasiswa sebelum membuat mind mapping diberikan garis besar materi yang telah ditentukan dan diberikan beberapa referensi untuk dibaca dan kemudian diolah ke dalam mind mapping. Pembuatan mind mapping juga dikawal dengan buku referensi mind mapping dari Tony Buzan. Pengerjaan mind mapping menggunakan beberapa media, media kertas (yang kemudian dijadikan versi pdf), Microsoft word, Microsoft Power Point, Canva, dan aplikasi mind mapping lainnya sesuai dengan kemampuan dan daya kreatifitas mahasiswa. Mahasiswa kemudian mengumpulkan tugas tersebut menggunakan Microsoft Form pada kolom tugas di Microsoft Teams.

Berikut beberapa contoh dari hasil mindmap menggunakan media yang berbeda:
Gambar 1: Mind mapping Zaman Prasejarah

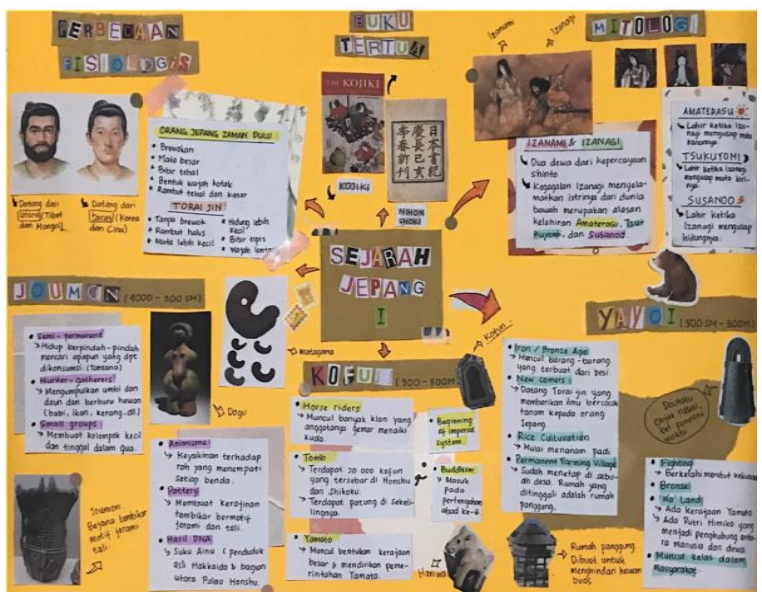

(Sumber: karya Adella Marshanda Karina)

Gambar 2: Mind mapping Zaman
Prasejarah

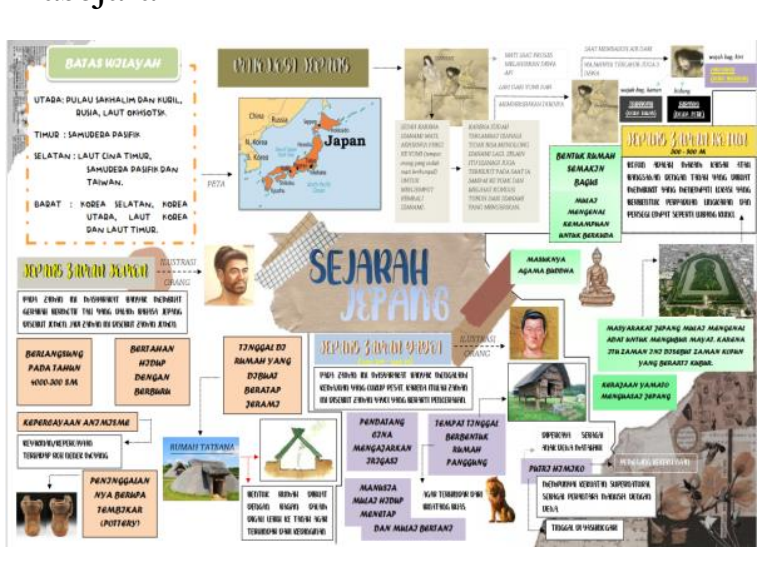

(Sumber: karya Fisca Aura Senandung Nacitha)

Gambar 3: Mind mapping Kerajaan Jepang Abad Pertengahan 


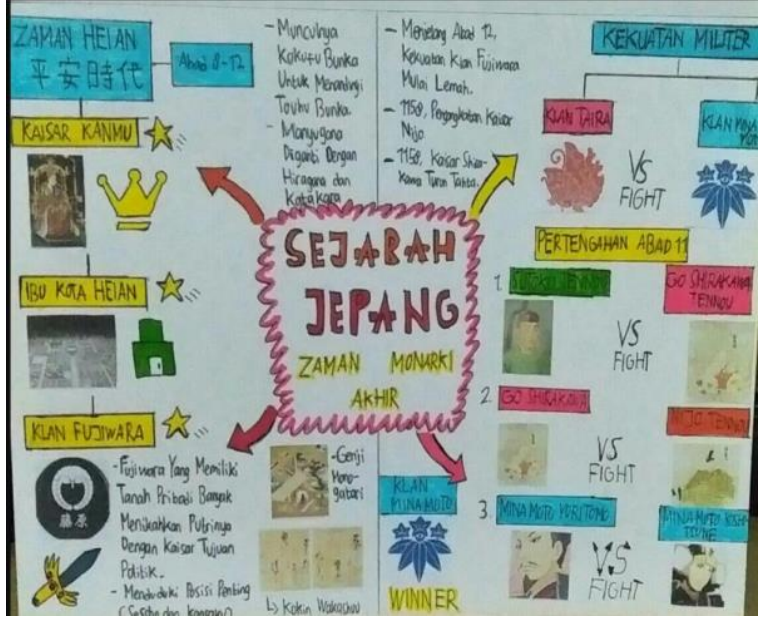

(Sumber: karya Hilmy Muhammad Irfani)

Gambar 4: Mind mapping Kerajaan Jepang Abad Pertengahan

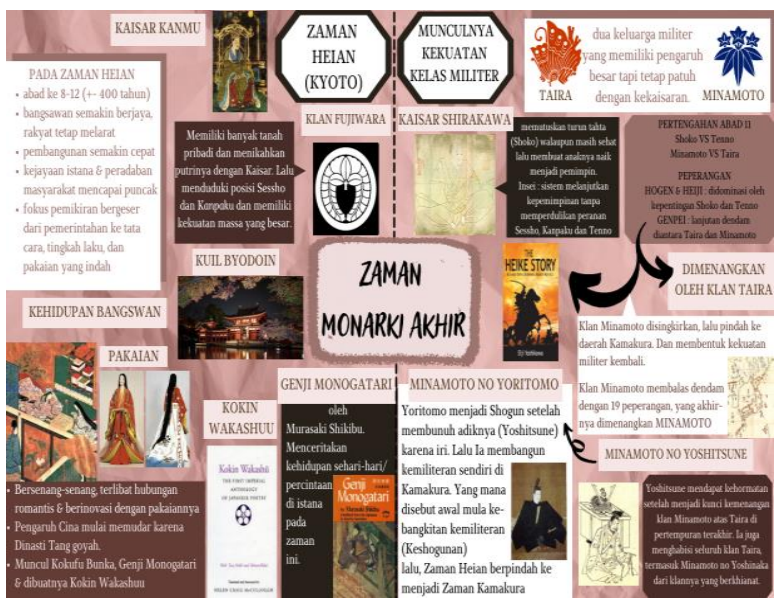

(Sumber: karya Nabila Iga Diandra

Tahap pengujian dilakukan di dua waktu sebagai berikut:

1. Minggu ketiga dimana pada minggu sebelumnya (minggu kedua) kelas B telah diberikan tindakan, sementara kelas A tidak.

2. Minggu kelima dimana pada minggu sebelumnya (minggu keempat) kelas A telah diberikan tindakan, sementara kelas B tidak

Bentuk pengujian dilakukan dengan review singkat di awal perkuliahan lalu dilanjutkan memberikan soal-soal singkat dalam bentuk pilihan ganda dan esai yang ahrus dikerjakan dalam waktu 5 menit. Tujuan dari waktu 5 menit ini adalah untuk melihat daya ingat mereka dan meminimalsir mahasiswa melihat buku referensi.

pelaksanaan penelitian dibagi menjadi 2 siklus dengan pergantian penerapan metode pemetaan pikiran di kelas $\mathrm{A}$ dan $\mathrm{B}$ dan diawali review singkat kepada mahasiswa mengenai kesan setelah membuat mind mapping mereka di awal kelas. Hasilnya semua mahasiswa merasa terbantu dengan adanya metode ini, karena selama membuat tugas tersebut, mereka menimati proses baca, berkreasi dalam menerapkan warna, membubuhkan gambar ataupun symbol. Secara alami, dalam proses tersebut mampu meinginternalisasi informasi-infrormasi yang diperoleh dari bahan referensi, sehhingga mudah bagi mereka untuk secara cepat dan tepat menggali kembali ingatan ketika dibutuhkan.

Adapun hasil pengujian dari 2 siklus pelaksanaan yakni sebagai berikut:

\subsection{Siklus Pertama}

Tindakan kelas diberikan kepada kelas B dengan mahasiswa sejumlah 39 orang. Pemberian materi masuk dalam kategori tingkat mudah yakni kehidupan pra sejarah manusia Jepang.

Dari hasil pengujian kelas B yang telah diberikan tindakan dan kelas A yang tidak diberi tindakan dengan responden masingmasing 39 mahasiswa secara umum menunjukkan bahwa kelas B mampu menjawab dengan skor rata-rata 77,1 poin, sementara kelas A mampu menjawab pertanyaan dengan skor rata-rata 49,1, hal ini mendekati perbandingan 1:2, sehingga dapat disimpulkan bahwa pada materi yang tingkatannya lebih mudah, metode mind 
mapping dapat meningkatkan pemahaman dua kali lipat dibanding mereka yang tidak menggunakan metode ini.

Pada soal pilihan ganda, kelas B meski tidak sampai pada ketepatan $100 \%$ mahasiswa dapat menjawab dengan benar, yakni dengan persentase $60 \%$ dapat menjawab dengan benar sesuai waktu yang ditentukan. Sedangkan pada soal cerita, dari beberapa soal yang diberikan, hanya 1 soal yang responnya tidak lengkap. Dan dari hasilnya, 99\% mahasiswa mampu menjawab dengan tepat dan lengkap.

Sementara untuk kelas A, pada soal pilihan ganda, mahasiswa sebanyak $46 \%$ dapat menjawab dengan benar sesuai waktu yang ditentukan. Sedangkan pada soal cerita, meski tidak menjelaskan dengan lengkap, mahasiswa masih dapat menyebutkan kata kunci-kata kunci yang mengarah pada ketepatan jawaban.

\subsection{Siklus Kedua}

Tindakan kelas diberikan kepada kelas A dengan mahasiswa sejumlah 43 orang. Pemberian materi masuk dalam kategori tingkat menengah yakni kehidupan sistem kerajaan Jepang abad pertengahan.

Dari hasil pengujian kelas A yang telah diberikan tindakan dan kelas B yang tidak diberi tindakan dengan responden masingmasing 43 mahasiswa menunjukkan bahwa kelas A mampu menjawab dengan skor rata-rata 66,3 poin, sementara kelas $B$ mampu menjawab pertanyaan dengan skor rata-rata 41 poin, hal ini juga dapat dikatakan hampir mendekati perbandingan 1:2, sehingga dapat disimpulkan bahwa pada materi yang tingkat kesulitannya level menengah, metode mind mapping dapat meningkatkan pemahaman dua kali lipat dibanding mereka yang tidak menggunakan metode ini, meski tidak semaksimal pada pengujian untuk materi yang lebih mudah di siklus sebelumnya.

Pada soal pilihan ganda, kelas A 100\% mahasiswa memberikan respond an jawaban, yakni dengan persentase $80 \%$ dapat menjawab dengan benar sesuai waktu yang ditentukan. Sedangkan pada soal cerita, dari beberapa soal yang diberikan, $100 \%$ mahasiswa menjawab. Dan dari hasilnya, $60 \%$ mahasiswa mampu menjawab dengan tepat dan lengkap, sementara sisanya hanya menyebutkan kata kunci dari jawaban yang benar.

Sementara untuk kelas B, pada soal pilihan ganda, mahasiswa pada soal, mahasiswa sebanyak 59\% dapat menjawab dengan benar sesuai waktu yang ditentukan. Sedangkan pada soal cerita, sebanyak $95 \%$ mahasiswa merespon soal. Meski tidak menjelaskan dengan lengkap, mahasiswa masih dapat menyebutkan kata kunci-kata kunci yang mengarah pada ketepatan jawaban.

\section{Simpulan}

Simpulan uang diperoleh dari hasil penelitian ini dapat adalah:

Penerapan metode pemetaan pikiran/Mind Mapping pada kelas Sejarah Jepang dapat membuat mahasiswa lebih antusias belajar daripada sebelumnya dimana mereka hanya menerima informasi 1 arah. Selain itu juga dikarenakan mereka bebas berkreasi dan berimajinasi di atas kertas kerja/media apa saja yang dapat digunakan untuk menulis dan menggambar, dalam proses tersebut materi pelajaran dapat diserap dengan alami tanpa perlu menghafalkannya.

Pada materi ajar yang tingkatannya lebih mudah, bagi mahasiswa yang menggunakan metode ini membuahkan hasil yang optimal 
dibandingkan dari hasil mahasiswa yang tidak menerapkan metode mind mapping, sedangkan pada materi ajar yang tingkat kesulitannya menengah, menunjukkan hasil yang sama pula.

\section{Referensi}

Akoojee and Nkomo. (2007). Teams_windows_x64 (Desktop).

Arikunto, S., Supardi, \& Suhardjono. (2015). Penelitian Tindakan Kelas: Vol. Edisi Revi (p. 260). PT Bumi Aksara.

https://books.google.co.id/books?id=RwmEAAAQBAJ\&pg=PA1\&source $=\mathrm{gbs} \_$toc_r $\&$ cad $=3 \# \mathrm{v}=$ onepage $\& \mathrm{q} \& \mathrm{f}$ $=$ false

Astawa, D. N. W. (2019). Influence of mind mapping method implementation on learning results social science is required from students interest. International Research Journal of Management, IT and Social Sciences, 6(3), 94-100. https://doi.org/10.21744/irjmis.v6n3.6 37

Buzan, T. (2004). Mind Maps at Work: How to be the best at your job and still have time to play (p. 141).

Buzan, T. (2005). Buku Pintar Mind Map (Terjemahan) (S. Purwoko (ed.); 6th ed.). PT Gramedia Pustaka Utama.

Buzan, T. (2018). Mind Map Mastery (p. 224). Watkins Publishing.

Diandra, Nabila Iga. (2021). Mind mapping Monarki Jepang di abad pertengahan. Kertas Kerja Mata Kuliah

Google. (n.d.). Google artsandculture. Retrieved September 3, 2021, from https://artsandculture.google.com/
Henshall, K. G. (1999). A History of Japan from Stone Age to Superpower. St. Martin's Press.

Irfani, Hilmy Muhammad. (2021). Mind mapping Monarki Jepang di abad pertengahan. Kertas Kerja Mata Kuliah

JDIH, B. R. (2005, December 30). UU No. 14 Tahun 2005 tentang Guru dan Dosen [JDIH BPK RI]. https://peraturan.bpk.go.id/Home/Det ails/40266/uu-no-14-tahun-2005

Karina, Adella Marshanda. (2021). Mind mapping Zaman Prasejarah Jepang. Kertas Kerja Mata Kuliah

Nachita, Fisca Aura Senandung. (2021). Mind mapping Zaman Prasejarah Jepang. Kertas Kerja Mata Kuliah

Nikhilkumar D. Parikh. (2016). Effectiveness of Teaching through Mind mapping Technique. International Journal of Indian Psychology, 3(3). https://doi.org/10.25215/0303.054

Nurhasanah, S., Jayadi, A., Sa'diyah, R., \& Syafrimen. (2019). Strategi Pembelajaran (A. Navitri (ed.)). Edu Pustaka.

Saiman, M. (2011). Inovasi Metode Pembelajaran Sejarah - Neliti. Lentera: Jurnal Ilmu-Ilmu Sejarah, Budaya Dan Sosial, 2(4), 73-85. https://www.neliti.com/id/publication s/22963/inovasi-metodepembelajaran-sejarah

Sudiarditha, K. R. (2011). Guidance of Classroom Action Research in Professional Development (Suryoto (ed.)). PT Bumi Timur Jaya. 